\title{
Creative Thinking Process on High Order Thinking Skills for Junior High School Students with Cognitive Style Field Independent
}

\author{
Ulil Albab ${ }^{1, *}$ Budiyono $^{2}$ Diari Indriati ${ }^{3}$

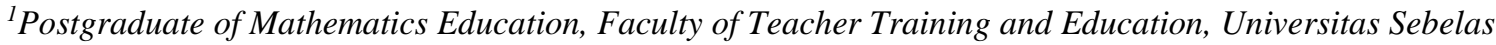 \\ Maret Surakarta, Indonesia \\ ${ }^{2}$ Faculty of Teacher Training and Education, Universitas Sebelas Maret Surakarta, Indonesia \\ ${ }^{3}$ Faculty of Mathematics and Natural Sciences, Universitas Sebelas Maret Surakarta, Indonesia \\ *Corresponding author. Email: albababie@gmail.com
}

\begin{abstract}
Creative thinking is an important ability needed by students in the 4.0 era as it is today. For this reason, this ability needs to be trained and developed in order to increase the potential and competitiveness of students. This study aims to describe the creative thinking process of students in solving HOTS problems in terms of field independent cognitive style. This research is a descriptive qualitative research. The selection of research subjects was carried out using Snowball Sampling. Research subjects were selected based on the results of a cognitive style test using a test instrument (GEFT) developed by Witkin. Data validation is done by triangulation of sources. Analysis of this research data using interactive analysis. The results of this study indicate that field independent cognitive students in the creative thinking process in the preparation stage of students tend to understand the questions in detail and can communicate the information contained in the questions in their own language. In the incubation stage, students tend to stop for a moment in understanding the problem and immediately think about how to get the question with the previous material that has been studied. In the illumination stage, students apply the problemsolving method with confidence according to the material on the problem, the subject solves it in a varied way. In the verification stage, students provide conclusions and re-examine the completion of mathematical problems, students try to correct them again until they are correct. Students with this cognitive style have the ability to think creatively to the level of fluency, flexibility, novelty, and tend to have creative thinking processes.
\end{abstract}

Keywords: Creative thinking process, Field independent cognitive style, HOTS question.

\section{INTRODUCTION}

Mathematics is a science that can train to think critically, systematically, logically, and creatively. Mathematics also has a strong and clear structure and linkage between concepts, thus enabling students to be skilled at rational thinking. Given this, it is important to study mathematics not only to know but also to try to understand and be able to apply it to other problems. Creative and critical thinking enables students to study problems systematically, face myriad challenges in an organized way, formulate innovative questions, and design original solutions. According [1] creative thinking is a mental activity that fosters original ideas and new understandings that require students to think systematically.

Creativity or creative thinking is needed to solve unexpected problems in everyday life. By thinking creatively, students are expected to be able to solve problems or problems with various ideas or broad ideas. [2] states that students who have the ability to think creatively fulfill the skills of fluent thinking, flexible thinking (flexible), original thinking, and detailed thinking (elaboration).

According to Nugroho [3] HOTS is a skill in processing and combining information in the form of facts and ideas that can be obtained by understanding, connecting, categorizing, and evaluating it. There are 
several indicators that a question is said to be HOTS, namely the question measures the level of cognitive reasoning (analyzes, evaluates, and creates) students, the problems given tend to be complex so that it has the possibility of more than one solution, information and ideas on the problem using interesting and innovative contextual stimuli thus encouraging students to think critically and creatively.

Many factors affect higher order thinking skills in students, one of which is students' cognitive style. The construction of knowledge by students is certainly influenced by various factors. Researchers want to see how students construct knowledge from their cognitive style. Cognitive style is the preferred way of individuals in organizing and processing information [4].

[5] revealed that cognitive style is a process or control style that arises in students which situationally can determine students' conscious activities in organizing, organizing, receiving, and disseminating information and also determines student behavior. Thus, cognitive style can be said as a way for students to capture information, process information and execute information in an action or behavior when the learning process takes place consistently. Cognitive styles can be distinguished based on several ways of grouping, to find one of them is done by Witkin [6] who identifies and categorizes a person based on the characteristics of the analytic global continuum. Based on this way of grouping, Witkin divides cognitive styles into 2 groups, namely field dependent and field independent cognitive styles. In this study, researchers are interested in analyzing the creative thinking process of higher order thinking skills at SMP Negeri 2 Mejobo Kudus in terms of field independent cognitive style.

\subsection{Creative Thinking Process}

Chaplin [7] argues that the process is any change in any object an organism, particularly a behavioral or psychological change, the point of which is that the process is a change, especially regarding changes in behavior or psychological changes. Thus, it can be concluded that the process is a series of actions that lead to progress regarding behavioral changes or psychological changes as well as producing products.

Mahmud [8] reveals that thinking in practice has 3 meanings, namely: thinking is an activity to explore formulas, thinking is an activity to interpret a real object into an abstract that is from expressing ideas and feelings in the form of images, writing, maps and others. On the other hand, thinking is the ability to draw conclusions from facts that have been understood.

Thinking processes occur in the minds of students when solving problems, so they can find solutions to mathematical problems. [9] states that with problem solving students will practice processing data or information, this data and information processing is called thinking. Meanwhile, Yulaelawati said that one of the teacher's roles in learning mathematics is to help students use the processes that run in students' minds when solving problems, for example by asking students to tell the steps that are in their minds. This is necessary to find out the thinking errors that occur and tidy up the students' knowledge network. For students, expressing the thought process is not easy. It needs positive thinking motivation, self-confidence, and good communication skills, a confident attitude can foster motivation to be able to solve math problems.

Based on the definitions of all the opinions above, the researcher concludes that the thinking process is a process or steps that begin with receiving data, processing and storing it in memory which is then retrieved from memory when needed for further processing. Because in the process of thinking in learning mathematics is a mental activity that is in the minds of students. Therefore, how students' thinking processes can be observed through the process of how to take tests and the results are written sequentially. In addition, there is an in-depth interview about how it works.

In the opinion of Silver [10] said that there are 3 indicators of creative thinking competence, namely: 1) Fluency is that students do the right questions and have the right value. 2) Flexibility is that students can find answers using various techniques and have the right value. 3) Novelty is a student showing a new way that is different from usual.

The creative thinking process of students can be measured using the theory proposed by Graham Wallas [11]. Wallas' stages in his book "The Art of Though" are preparation, incubation, illumination and verification. The stages of the creative thinking process proposed by Graham Wallas consist of four stages, namely preparation is this stage, the thinking process will be seen from the start of students receiving questions until students write and mention what they know and are asked about, incubation is the stage of This stage will see students' thinking processes in thinking about ideas to solve questions, illumination is this stage, students' thinking processes will be seen in finding new solutions to problems and materials that have been obtained previously. students think in re-examining the results that have been written by writing conclusions.

\subsection{Field Independent Cognitive Style}

Learning is a process of receiving and processing information into knowledge. From a psychological point of view, each individual has different 
characteristics in processing this information into new knowledge. The characteristics inherent in individuals about how to receive and process the information received are referred to as cognitive styles [12], defines cognitive style as strategies, choices, and attitudes that are characteristic of a person in understanding, remembering and solving problems.

According to Coop and Sigel [12] cognitive style has a correlation with intellectual and perceptual behavior. Intellectual is related to one's ability to think, while perceptual is related to one's ability to perceive or interpret something. According to Witkin, Moore, Goodenough, \& Cox (1975) there are two dimensions in cognitive style, namely, Field-Independent (FI) and Field-Dependent (FD). Witkin, Moore, Goodenough, \& Cox (1975) explain that individuals who have a Field-Independent cognitive style are able to abstract elements from the context or background from the context. Characteristics of students who have FieldIndependent cognitive style are classified, among others: (1) have the ability to analyze to separate objects from the surrounding environment, so that their perception is not affected when the environment changes; (2) have the ability to organize objects that are not yet organized and reorganize objects that have been organized independently; (3) tend to be less sensitive, cold, keep a distance from other people, and individualistic, characterized by interactions with other people carried out as necessary; (4) choosing a profession that can be done individually with material that is more abstract or requires theory and analysis; (5) tend to define their own goals and work alone but prefer to compete; and (6) tend to work with an emphasis on intrinsic motivation and is more influenced by intrinsic reinforcement.

\subsection{HOTS questions}

High Order Thinking Skills (HOTS) is a thinking process that involves mental activity in an effort to explore complex, reflective and creative experiences that are carried out consciously to achieve goals, namely obtaining knowledge which includes levels of analytical, synthetic, and evaluative thinking [13]. Higher order thinking ability is defined as a thinking skill that not only requires remembering, memorizing and understanding skills but requires other higher skills.

Table 1. The relationship between Wallas creative thinking process and creative thinking components according to silver.

\begin{tabular}{|c|c|c|}
\hline $\begin{array}{l}\text { Creative Thinking } \\
\text { Process According to } \\
\text { Wallas }\end{array}$ & $\begin{array}{l}\text { Creative } \\
\text { Thinking } \\
\text { According } \\
\text { to Silver }\end{array}$ & Description \\
\hline \multirow[t]{2}{*}{ Preparation } & & $\begin{array}{l}\text { At this stage, the thinking process will be seen from the time the } \\
\text { students receive the questions until the students write down and } \\
\text { mention what they know and are asked in the questions. }\end{array}$ \\
\hline & Fluency & $\begin{array}{l}\text { Students explore open-ended problems to create many questions } \\
\text { and answer correctly. }\end{array}$ \\
\hline \multirow[t]{2}{*}{ Incubation } & & $\begin{array}{l}\text { At this stage, the students' thinking process will be seen in thinking } \\
\text { about ideas to solve questions. }\end{array}$ \\
\hline & Flexibility & $\begin{array}{l}\text { Students in looking at problems through various points of view so as } \\
\text { to produce a lot of thoughts and can answer using various ways of } \\
\text { solving. }\end{array}$ \\
\hline \multirow[t]{2}{*}{ Illumination } & & $\begin{array}{l}\text { At this stage, students' thinking processes will be seen in finding new } \\
\text { solutions to problems and materials that have been obtained } \\
\text { previously. }\end{array}$ \\
\hline & Novelty & $\begin{array}{l}\text { Competence of students to provide solutions that are different from } \\
\text { their friends and have the correct value. }\end{array}$ \\
\hline Verification & & $\begin{array}{l}\text { At this stage, the students' thinking process will be seen in re- } \\
\text { examining the results that have been written by writing conclusions. }\end{array}$ \\
\hline
\end{tabular}


According to Saputra [14] states that higher-order thinking is a thinking process for students at a higher cognitive level developed from various cognitive concepts and methods and learning taxonomies such as problem-solving methods, bloom taxonomy, and taxonomy of learning, teaching, and assessment. Problem solving is a method used to solve problems that cannot be solved using routine procedures, but must be solved to achieve goals by using the knowledge, skills, and understanding possessed. The indicators used in the study to analyze Higher Order Thinking Skills in problem solving refer to the opinion of Krathwohl and Anderson. Indicators to measure Higher Order Thinking Skills with Analysis indicators (C4) Students can determine how an element fits or functions in a structure or organization, Evaluating indicators (C5) Students can make decisions about the data presented, which data is correct to answer the questions asked obtained, the indicator Creating (C6) Students make designs with certain criteria, namely the designs they make must follow the rules that have been set.

\section{METHODOLOGY}

\subsection{Participants}

This research used a qualitative descriptive study, which describes students' spatial intelligence in problem-solving. Qualitative methodology is a research procedure that produces descriptive data in written or spoken words from people and observed behavior [11]. Qualitative research describes the data without any manipulation [12].

\subsection{Design of the Study}

The research was carried out in class VIII G of SMP Negeri 2 Mejobo Kudus in the 2020/2021 academic year, where there were 32 students as research subjects. The field independent cognitive style research instrument (FI) has 25 questions with 3 working sessions, the first session 7 questions as a test and the second session, the third as the score for determining the cognitive style value of 18 questions. The results of the field independent cognitive style test (FI), from 32 students the number of students who had a field independent cognitive style (FI) was $43.75 \%$.

\subsection{Instrumental}

The researcher chose to analyze the creative thinking process of Wallas and connect it by looking at the achievement of creative thinking according to Silver. Where in each stage there is a component of the creative thinking process that can be seen as a component to measure students' creative thinking skills in solving a mathematical problem. The creative thinking component according to Silver in [10] consists of three components, namely fluency, flexibility and novelty. The following is a table of relationships between Silver's creative thinking components and Wallas' creative thinking process stages as shown in Table 1.

Table 1 shows that there is a relationship between the two indicators of creative thinking according to Wallas and Silver. The researcher gave a synthesis based on the description of each indicator that the stages of the creative thinking process would be able to see the level of achievement of students' creative thinking. Students who can work on the stages of the creative thinking process Preparation and incubation, then these students can reach the level of creative thinking fluency. Students who can work on the stages of the creative thinking process Preparation and incubation, and illumination, then these students can reach the level of creative thinking Flexibility. Students who can work on the creative thinking process stage Preparation, Incubation, Illumination, and Verification, then these students can reach the level of creative thinking Novelty.

\section{RESULTS AND DISCUSSION}

\subsection{FI-1 Subject Analysis}

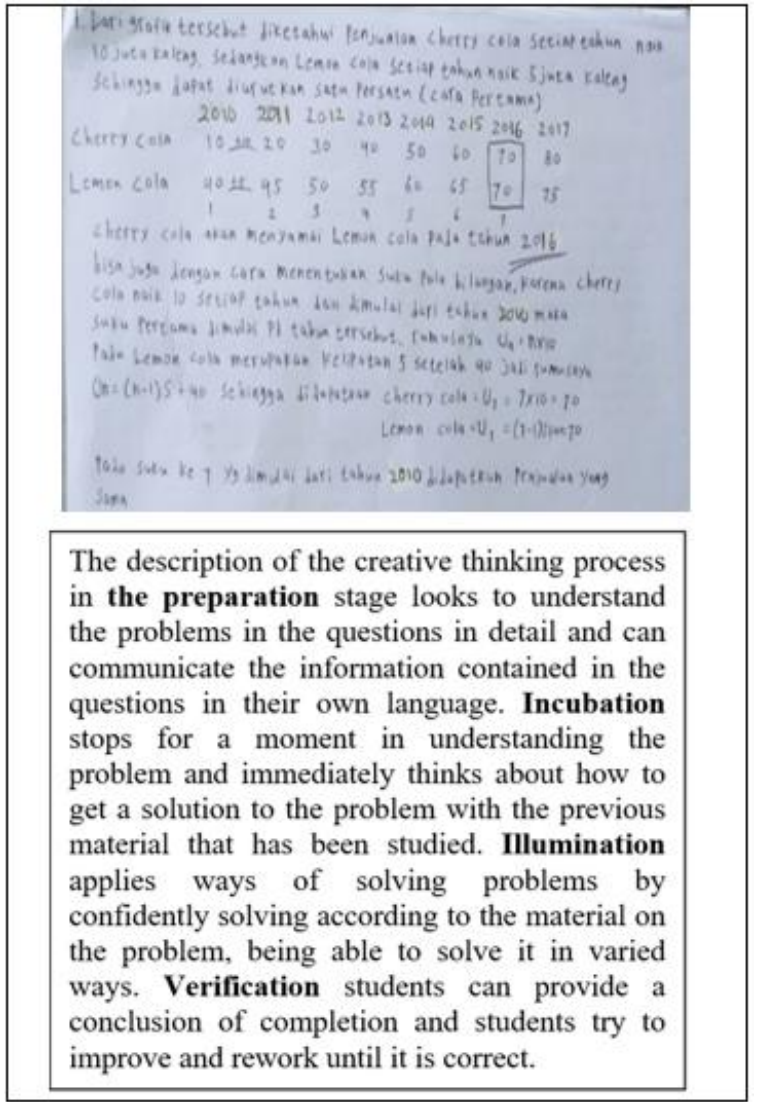

Figure 1. FI-1 written test answers 
Based on the results of answers in Figure 1, interview observations in the FI-1 preparation process seemed to understand the problems in the questions in detail and were able to communicate the information contained in the questions in their own language, describe in detail what information was meant in the questions, it was seen that the subject wrote that there was a pattern or line. In the diagram, Cerry has plus 10 and Lemon has added 5. In the incubation process, FI1 seems to stop for a moment in understanding the problem and immediately think about how to get the problem with the previous material that has been studied, in the first way using the idea by making a row of patterned numbers which was written sequentially from year to year starting in 2010 so that the same year of sales was obtained between shof dring chary and lemon in 2016. In the FI-1 illumination process, it was seen that he applied ways to solve problems by confidently solving according to the material in the problem, able to solve the problem. in a varied way, in the second method using a solution by formulating a mathematical concept of number pattern terms, to find the order in which cherries and lemons have the same sales value, FI-1 seems to find that in the 7th term cherries and lemons have the same sales., if it is calculated from the first year of sales in 2010 it is 7 th in 2016. In the verification process, it can be seen that the sales results were the same in 2016 namely sales both reached 70 million with different concepts. From the results of writing FI-1 is able to explore open problems in order to create many questions and answer correctly.

After analyzing the results of taking written test data and observations, supported by interviews, it can be concluded that the subject of FI-1 is able to explore open problems in order to create many questions and answer correctly in solving HOTS problems. And in the creative thinking process is also complete in preparation, incubation, illumination and verification. Then the subject of FI-1 meets the indicators of Fluency, Flexibility, Novelty.

Researchers are trying to ensure the validity of the description findings from FI students, so a second research subject is needed to explore how the descriptive data of creative thinking processes with FI cognitive style are so that the findings of the data obtained are the same and it can be said that the data is saturated.

\subsection{FI-2 Subject Analysis}

Based on the results of written answers in Figure 2 and observations from FI-2 at the preparation stage, it seems that they understand the problems in the questions in detail and can communicate the information contained in the questions in their own language, can write and understand what information is needed to solve the problems, it seems that FI-2 can make mathematical model with algebraic form by eg eating, stationery 2, and SPP so that the value sought becomes in all aspects, at the incubation stage FI-2 looks to stop for a moment in understanding the problem and immediately think about how to get the solution to the problem with the previous material what has been learned, evaluates the information to be used as a basis for determining the settlement method to be used, it appears that FI-2 determines the value that is already known 7, then that value is divided with the money owned by risk. it can be seen that FI-2 is fluent in the logic of comparisons to algebraic forms. At the illumination stage FI-2 looks to apply ways to solve problems by confidently solving according to the material in the problem, but the subject is only able to answer using one way of solving the problem, namely by algebraic operations.

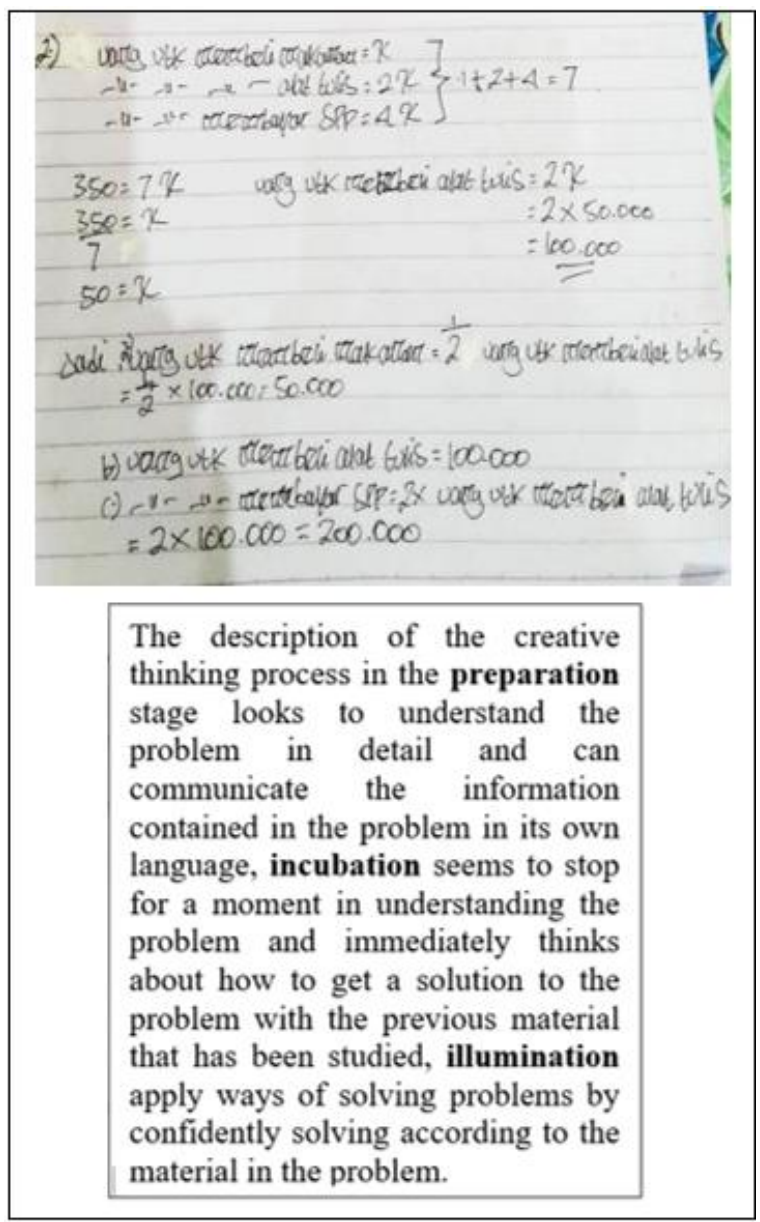

Figure 2. FI-2 written test answers

After analyzing the results of taking written test data and observations, supported by interviews, it can be concluded that the subject of FI-2 is able to look at the problem through various varied perspectives so that it generates a lot of thoughts and can answer using 
various ways in solving HOTS problems and in the creative thinking process is also complete. on preparation, incubation, illumination. FI-2 subject meets the Fluency, Flexibility, Novelty indicator.

Researchers have not seen and confirmed the validity of the findings of descriptive data from FI students at the verification stage, so a third research subject is needed to explore how the thinking process with the FI cognitive style is until the data findings are said to be saturated.

\subsection{FI-3 Subject Analysis}

Based on the results of written answers in Figure 3 and observations from FI-3 at the preparation stage, it seems that they understand the problems in the questions in detail and can communicate the information contained in the questions in their own language. the side value of the initial shape of the mirror is $5 \mathrm{~cm}$, then at the incubation stage FI-3 seems to stop for a moment in understanding the problem and immediately think about how to get the solution to the problem with the previous material that has been studied, evaluate the information to be used as a basis for determining how to solve the problem. which will be used, it can be seen that FI-3 makes the shape of a parallelogram and a right triangle. At the illumination stage, FI-3 is also seen applying ways to solve problems by confidently solving according to the material on the problem, being able to solve in varied ways, being able to answer using two different ways to solve the problem. F1-3 in the form of a parallelogram can be seen. prove the value of the parallelogram area of $24 \mathrm{~cm} 2$, the second way is to choose a right triangle with a base of $8 \mathrm{~cm}$, a height of $6 \mathrm{~cm}$ and a hypotenuse of $10 \mathrm{~cm}$. This triangular shape also has the same area as the initial mirror area, which is $24 \mathrm{~cm} 2$, it is proven that FI-3 is creative in making what objects are right for other mirror shapes. At the verification stage, F1-3 seems to be able to provide conclusions and re-examine the solution of mathematical problems, students try to repair and rework until they are correct, they can also check the shape of the mirror with many shapes and calculate the area, circumference and hypotenuse of each object.

After analyzing the results of taking written test data and observations, supported by interviews, it can be concluded that the subject of FI-3 is able to look at the problem from various perspectives so that it produces many thoughts and can answer using various ways in solving HOTS problems and in the creative thinking process. preparation, incubation, illumination and verification. Then the subject of FI-3 meets the Novelty indicator.

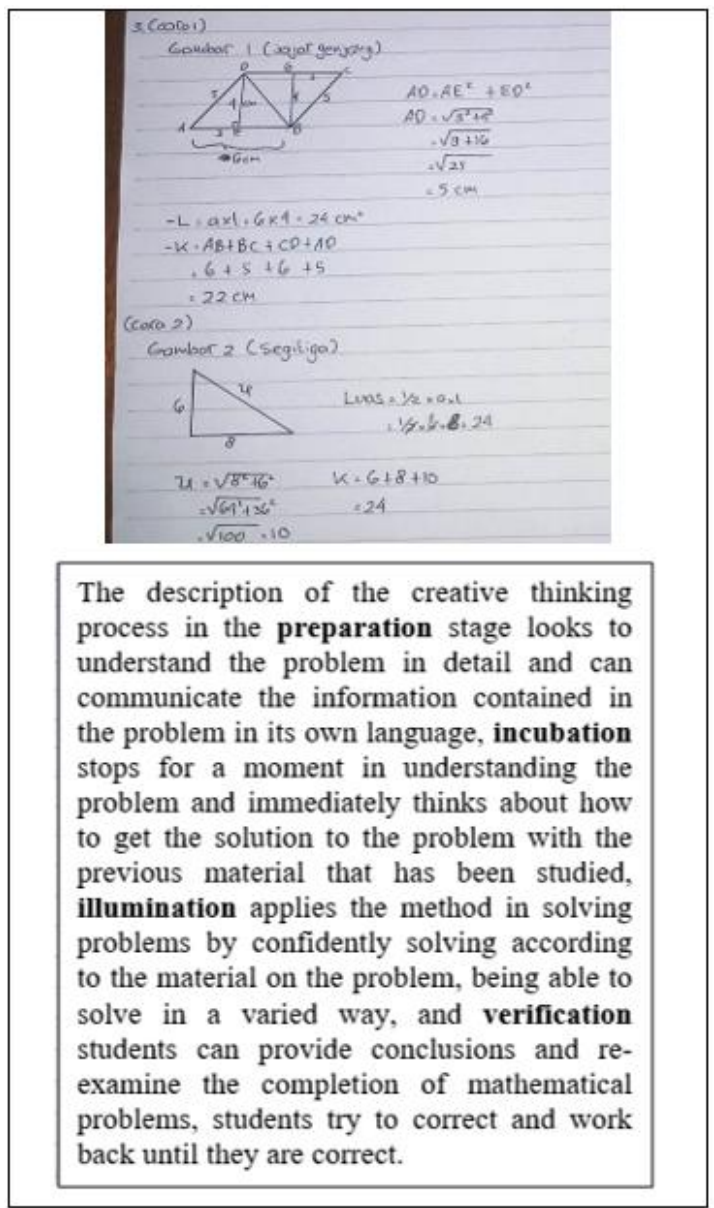

Figure 3. FI-3 written test answers

Researchers have been able to confirm the validity of the description findings from FI students at the preparation stage. incubation, illumination and verification, the research subject was stopped on the third research subject, because the information or data obtained was saturated, which means that the information provided by the research subject has similarities with other research subjects.

A summary description of the third subject that has been presented can be seen in Table 2 .

Table 2. Creative thinking process students are field independent on HOTS questions

\begin{tabular}{|l|l|l|l|l|}
\multicolumn{1}{|c|}{ Subject } & \multicolumn{1}{|c|}{ Preparation } & \multicolumn{1}{c|}{ Illumination } & \multicolumn{1}{c|}{ Verification } \\
\hline $\mathrm{FI}-1$ & Visible & Visible & Visible & Visible \\
\hline $\mathrm{FI}-2$ & Visible & Visible & Visible & Not visible \\
\hline $\mathrm{FI}-3$ & Visible & Visible & Visible & Visible \\
\hline
\end{tabular}




\section{DISCUSSION}

Students with field independent cognitive style at the stage of the creative thinking process when the preparation stage field independent students tend to understand the problems in the questions in detail and can communicate the information contained in the questions in their own language. At the incubation stage, students tend to stop for a moment in understanding the problem and immediately think about how to get the question with the previous material that has been studied. At the illumination stage, students apply ways of solving problems by confidently solving them according to the material on the problem, being able to solve them in varied ways. At the verification stage students are able to provide conclusions and re-examine the completion of mathematical problems, students try to improve and rework until they are correct.

Field independent cognitive style students seen in the creative thinking process can only reach the stage of the thought process of preparation, incubation, illumination and verification. In terms of HOTS, the level of analysis, evaluation, and creation is capable. So the creative thinking component reaches the level of fluency, flexibility, novelty. This means that field independent cognitive style students tend to understand questions in detail and in detail in describing, varied in solving problems, can solve in many ways, and can re-examine the answers that have been written. The thinking process of students with field independent cognitive style is also active in acting, this is shown during the test and interview process, field independent students can immediately get a solution after knowing the problems presented in the questions in detail and precisely based on their own thoughts. Field independent cognitive style students tend to think creatively, meaning that students with this cognitive style process thinking in solving HOTS. problems can solve them in varied ways.

\section{ACKNOWLEDGMENTS}

The researcher would like to thank all parties who have helped the research process, especially the 8th grade students of SMP N 2 Mejobo Kudus, and the validators of research instrument.

\section{REFERENCES}

[1] Johnson, E. B. 2007. Contxtual Teaching and Learning: Menjadikan Kegiatan BelajarMengajar Mengasyikkan dan Bermakna. Bandung: Mizan Learning Center (MLC).

[2] Munandar, U. 2014. Pengembangan Kreativitas Anak Berbakat. Jakarta: Rineka Cipta.
[3] Nugroho, A. (2018). HOTS Kemampuan Berpikir Tingkat Tinggi. Jakarta: Grasindo.

[4] Mefoh, P. C., et al. (2017). Effect of cognitive style and gender on adolescents' problemsolving ability. Thinking Skills and Creativity, $25,47-52$.

[5] Bassey, Sam. W \& Umoren, Grace. 2009. Cognitive Styles, Secondary School Students'Attitude and Academic Performance in Chemistry in Akwalbom State-Nigeria.

[6] Witkin, A. H. et al. (1977). "Field-Dependent and Independent Cognitive Style and Thei Educational Implication".Review of Educational Research, 47 (1), hlm 1-64.

[7] Muhibbin, (2009). Psikologi Belajar. Jakarta: Rajawali Pers

[8] Purwaningrum (2016). Mengembangkan kemampuan berpikir kreatif matematis melalui discovery learning berbasis scientific approach. Jurnal UMK. Vol 6, No 2 (2016).

[9] Herman, \& Hudojo. (2005). Pengembangan Kurikulum dan Pembelajaran Matematika. Malang: UM Press.

[10] Richardo, R., Mardiyana., \& Saputro. D. R. S. (2014). "Tingkat Kreativitas Siswa Dalam Memecahkan Masalah Matematika Divergen Ditinjau Dari Gaya Belajar Siswa (Studi Pada Siswa Kelas Ix Mts Negeri Plupuh Kabupaten Sragen Semester Gasal Tahun Pelajaran 2013/ 2014)". Jurnal, 2(2): 141.

[11] Shofiyah U, 2019. Profil berpikir kreatif siswa berkepribadian koleris dalam menyelesaikan soal aljabar. Jember : Kadikma : Vol.10, No.2, hal. 29-43, 2019.

[12] Hidayat, D., Amin, S. M., \& Fuad, Y. (2018). Implementation of Lesson Study in Mathematics Learning Based on Student Cognitive Style. Advances in Engineering Research, 175, 84-87.

[13] Rofiah, E., Aminah, N. S., \& Ekawati, E.Y. (2013). Penyusunan Instrumen Tes Kemampuan Bepikir Tingkat Tinggi Fisika Pada Siswa SMP.Jurnal Pendidikan Fisika.1, (2), 17-22.

[14] Dinni, H. N. (2018). HOTS (High Order Thinking Skills) dan Kaitannya dengan Kemampuan Literasi Matematika.Prisma. 1, (1), 170-176. 